\title{
Osoba z niepełnosprawnością na drodze aktywizacji zawodowej - wybrane problemy a realia współczesnej rzeczywistości społecznej
}

\author{
Disabled person on the road to professional activation - \\ selected issues related to the realities of contemporary \\ social reality
}

\begin{abstract}
Streszczenie. Wśród osób, których bezrobocie dotyka szczególnie drastycznie znajdują się osoby niepełnosprawne, które z powodu niepełnosprawności, związanych z niepełnosprawnością ograniczonych możliwości funkcjonalnych, jak również pokutujących w mentalności ogólnospołecznej postaw wobec tego zagadnienia (obecnych także wśród potencjalnych pracodawców) stanowią poważny determinant i istotną przeszkodę w zatrudnianiu niepełnosprawnych adekwatnie do uzyskanego przez nich wykształcenia oraz pozyskanych kompetencji zawodowych. W treści artykułu została naświetlona sytuacja osób niepełnosprawnych na rynku pracy w Polsce z uwzględnieniem województwa warmińsko-mazurskiego; podano również czynniki warunkujące dany stan rzeczy, tkwiące zarówno w kontekstach historyczno-kulturowych, ogólnospołecznych, jak i wynikające bezpośrednio ze stanu niepełnosprawności.
\end{abstract}

Słowa kluczowe: niepełnosprawność, osoba niepełnosprawna, rehabilitacja, edukacja, rehabilitacja zawodowa, edukacja zawodowa.

Summary. Disabled people are particularly affected by unemployment. This is mostly because their disability is also related to the fact that they display limited functional capabilities. Additionally, the social prejudice of the populace is present within the minds of potential employers. These are serious determinants and major obstacles for employment of disabled adequate to their education and job expertise. This article highlights the situation of disabled people on the job market in Poland while taking into account the situation in Warmian-Masurian Voivodship. Also, it outlines the factors conditioning the current state 
which are rooted in history and culture as well as in social contexts or even arising directly from the state of disability.

Keywords: disability, disabled person, rehabilitation, education, vocational rehabilitation, vocational education.

\section{Wprowadzenie}

Osoby niepełnosprawne należą do tych grup społecznych, które potrzebują szczególnej uwagi oraz wsparcia w różnych sferach i zakresach ich społecznego, jak również indywidualnego, osobistego funkcjonowania.

Wsparcie społeczne szeroko ujętego środowiska ludzi z niepełnosprawnością można postrzegać w niejednoznacznych, nietożsamych oraz zróżnicowanych kategoriach. Na ogół jest ono zależne od: typu niepełnosprawności i jej konsekwencji (zasadniczo wynikających ze stanu niepełnosprawności), ale też od jakości, celowości, efektywności, profesjonalizmu oferowanego i rzeczywiście udzielanego wsparcia społecznego.

Do sfer aktywności życiowej osoby niepełnosprawnej, gdzie wsparcie społeczne jest wymagane, przeważnie włącza się obszar rehabilitacji, edukacji, aktywności społecznej, zawodowej, kulturalnej, odpoczynku i rekreacji. W każdym z tych obszarów człowiek z niepełnosprawnością prezentuje zróżnicowane potrzeby i oczekiwania wobec osób i instytucji udzielających wsparcia oraz wobec siebie samego, jako tego wsparcia adresat. Wśród niepełnosprawnych dużym problemem, poza kwestiami rehabilitacji, edukacji, aktywności społeczno-kulturalnej oraz rekreacyjnej, jest kwestia aktywności zawodowej, a w tym poszukiwania, uzyskania oraz utrzymania zatrudnienia w miejscu pracy (pomijam w tym miejscu kwestię awansu zawodowego, który dla każdego pracownika stanowi określone wyzwanie i ważny cel jego profesjonalnej aktywności).

\section{Sytuacja osób niepełnosprawnych na rynku pracy na przykła- dzie województwa warmińsko-mazurskiego}

Aktywność zawodowa osób niepełnosprawnych w Polsce, w roku 2011, szacowana była na około 16\%. Wskaźnik ten w krajach Unii Europejskiej wynosił 40-50\% (Raport o osobach niepełnosprawnych w Polsce, 2011). Przyczyn takiego stanu rzeczy jest wiele. Istotny jest fakt, że tylko 5\% pracodawców 
w Polsce wyrażało zainteresowanie zatrudnieniem osoby niepełnosprawnej, a z 10,5\% wydatków publicznych przeznaczanych na rozwiązywanie problemów ludzi z niepełnosprawnością, jedynie $0,2 \%$ tego wskaźnika stanowiły wydatki związane z zatrudnieniem osób niepełnosprawnych (Raport o osobach niepełnosprawnych w Polsce, 2011).

Zagadnienie aktywizacji zawodowej, ze szczególnym uwzględnieniem działań dotyczących przygotowania do pracy, poszukiwania pracy i utrzymania pracy przez osobę niepełnosprawną, jest istotne z cywilizacyjnego, kulturowego, społecznego oraz jednostkowego punktu widzenia.

Dla przykładu w grudniu 2013 roku niepełnosprawni bezrobotni na terenie Warmii i Mazur ${ }^{1}$ stanowili 5,6\% ogółu bezrobotnych w tym regionie (to liczba 6536 osób). W roku 2012 takich osób było 693 (tj. o 11,9\% mniej). Nastąpił więc wzrost liczby zarejestrowanych bezrobotnych niepełnosprawnych o 0,4 pkt. procentowego w relacji do roku 2012. W porównaniu z rokiem 2011 liczba bezrobotnych zwiększyła się o 908 osób (tj. o 16,1\%).

W 2013 roku w rejestrach powiatowych urzędów pracy pozostawało 986 osób niepełnosprawnych poszukujących pracy i niepozostających w zatrudnieniu. W porównaniu z rokiem 2011 liczba ta spadła o 32 osoby (3,1\%), a w porównaniu z rokiem 2012 o 20 osób (2,0\%). Mimo spadku liczby niepełnosprawnych poszukujących pracy ogólna liczba niepełnosprawnych zarejestrowanych w urzędach pracy, w porównaniu z rokiem 2011, była większa o 876 osób (o 13,2\%), a w porównaniu z rokiem 2012 o 673 osoby (9,8\%). W roku 2013 najwięcej zarejestrowanych niepełnosprawnych bezrobotnych było w powiecie Olsztyn Grodzki (672 osoby, 9,2\% niepełnosprawnych bezrobotnych w województwie) i ostródzkim (599 osób, 6,6\%), najmniej w powiecie węgorzewskim (104 osoby, 4,4\%) i oleckim (124 osoby, 3,8\%).

W roku 2013 ponad połowę niepełnosprawnych bezrobotnych w województwie warmińsko-mazurskim stanowiły kobiety (51,9\% - 3392 osób). W porównaniu z rokiem 2011 liczba bezrobotnych kobiet wzrosła o 399 osób (13,3\%), a z rokiem 2012 o 429 osób (o 14,5\%); 61,3\% niepełnosprawnych bezrobotnych w tym roku mieszkało w miastach, a co piąty niepełnosprawny bezrobotny posiadał prawo do zasiłku z tytułu pozostawania bez pracy.

1 Wszystkie dane na temat sytuacji osób niepełnosprawnych na rynku pracy w województwie warmińsko-mazurskim przedstawiono na podstawie opracowania: Wojewódzki program wyrównywania szans i przeciwdziałania wykluczeniu społecznemu oraz pomocy $w$ realizacji zadań na rzecz zatrudniania osób niepełnosprawnych na lata 2012-2015. Monitoring działań w 2013 roku w obszarze: bezrobotne osoby niepetnosprawne, Wojewódzki Urząd Pracy, Olsztyn 2013. 
Osoby z lekkim stopniem niepełnosprawności stanowiły 64,6\%, a ze stopniem umiarkowanym 33,5\% ogółu niepełnosprawnych bezrobotnych zarejestrowanych w urzędach pracy w roku 2013.

Wśród niepełnosprawnych bezrobotnych przeważały osoby z niepełnosprawnością ruchową (31,7\%), zatem: z chorobami neurologicznymi $(13,2 \%)$, niepełnosprawnością wzrokową (9,3\%), chorobami układu oddechowego i krążenia (9,3\%), psychicznymi (8,8\%), zaburzeniami głosu, mowy i słuchu (6,4\%), z niepełnosprawnością intelektualną i epilepsją (2,8\%).

Szacuje się, że 58,5\% niepełnosprawnych bezrobotnych to osoby w przedziale wiekowym powyżej 45, a do 54 roku życia; 32,9\% niepełnosprawnych bezrobotnych legitymowało się wykształceniem podstawowym lub niepełnym podstawowym, 32,2\% zawodowym, 19\% policealnym lub średnim zawodowym, 8,1\% średnim ogólnokształcącym, 5,3\% wyższym; $38,8 \%$ zarejestrowanych niepełnosprawnych bezrobotnych pozostawało bez pracy dłużej niż 12 miesięcy. W analizowanym roku, tj. 2013, pracodawcy z terenu województwa warmińsko-mazurskiego zgłosili dla osób niepełnosprawnych 1999 ofert pracy i miejsc aktywizacji zawodowej, co w relacji do roku 2012 oznacza wzrost o 326 ofert (tzn. o 19,5\%); 89\% ofert pracy (1780) stanowiły propozycje zatrudnienia lub aktywizacji zawodowej. Ponadto zgłoszono 219 ofert aktywizacji zawodowej, spośród których 158 dotyczyło stażu, a 61 prac społecznie użytecznych. W danym roku zauważono wzrost przyjęć do pracy osób niepełnosprawnych bezrobotnych - z 2978 w roku 2012 do 3249 (o 271 osób więcej, tj. o 9,1\%).

Z grona osób, które podjęły pracę w roku 2013, 651 uzyskało tzw. pracę subsydiowaną ze środków Państwowego Funduszu Rehabilitacji Osób Niepełnosprawnych, w tym 62 osoby zatrudniono na miejscach subsydiowanych ze środków PFRON (w tym 2 w zakładach pracy chronionej); 77 osób zatrudniono na miejscach subsydiowanych ze środków Funduszu Pracy, 90 osób podjęło działalność gospodarczą. Pracę niesubsydiowaną podjęło 2598 osób, spośród których 199 osób uczestniczyło w pracach sezonowych, 56 podjęło działalność gospodarczą.

W roku 2013 w województwie warmińsko-mazurskim z różnych form aktywizacji zawodowej (szkolenia, staże, przygotowanie zawodowe dorosłych, prace społecznie użyteczne) uczestniczyły 933 osoby niepełnosprawne: 421 uczestniczyły w stażach u pracodawcy, 292 w pracach społecznie użytecznych, 219 w szkoleniach.

W porównaniu do roku 2012 wzrosła liczba osób uczestniczących w podanych formach aktywizacji zawodowej; staże o 6,6\%, szkolenia o 3,8\%, 1 osoba więcej uczestniczyła w przygotowaniu zawodowym dorosłych. Jed- 
nakże w roku 2013 status osoby bezrobotnej utraciło 8712 osób niepełnosprawnych. Najwięcej osób wyrejestrowano z powodu podjęcia pracy niesubsydiowanej (2598 - 29,8\%), z powodu utraty statusu osoby niepełnosprawnej (18,9\%), z powodu rezygnacji lub niepotwierdzenia gotowości do pracy (1280 osób - 14,7\%).

Stopa bezrobocia w sierpniu 2014 roku w Polsce wyniosła w kraju 11,7\%i była o $0,1 \%$ niższa od tej w lipcu - podaje GUS. W urzędach pracy na koniec sierpnia było zarejestrowanych 1853200 osób. Najwyższa stopa bezrobocia nadal utrzymywała się na Warmii i Mazurach. Pracy nie miało $18,4 \%$ czynnych zawodowo mieszkańców tego regionu. Ponadto w danym województwie w sierpniu 2014 roku był największy wzrost bezrobotnych. Tak zwana stopa napływu w urzędach pracy wyniosła $1,8 \%$.

Podsumowując powyższe dane, warto podkreślić niezwykle skomplikowaną sytuację zawodową osób z niepełnosprawnością na terenie Warmii i Mazur. Przyczyny danego stanu rzeczy mogą być następujące: wysoki wskaźnik bezrobocia, geopolityczna i gospodarcza specyfika regionu, sytuacja społeczno-polityczna kraju, oferowana liczba miejsc pracy, niepełnosprawność, tratowanie środowiska osób niepełnosprawnych jako źródła ewentualnie możliwego dochodu przez pozyskiwanie dotacji ze środków Państwowego Funduszu Rehabilitacji Osób Niepełnosprawnych.

\section{Uwarunkowania społeczno-kulturowe i indywidualne sytuacji na rynku pracy osób niepełnosprawnych}

Przy analizie zagadnienia uwarunkowań, a szczególnie obszarów uwarunkowań aktualnej sytuacji osób niepełnosprawnych na rynku pracy, pojawia się kilka z nich: obszar uwarunkowań historyczno-kulturowych, związany z specyfiką rozwoju współczesnej cywilizacji, związany ze specyfiką aktualnych społeczno-politycznych działań na rzecz osób niepełnosprawnych, związany z osobą niepełnosprawną oraz związany z osobami pełnosprawnymi.

1. Obszar uwarunkowań historyczno-kulturowych:

- historycznie utrwalony w ogólnospołecznych postawach stosunek do osób niepełnosprawnych w kontekście globalnym oraz wobec konkretnych typów niepełnosprawności; 
- historycznie utrwalona percepcja możliwości rozwojowo-funkcjonalnych osób niepełnosprawnych oraz osób z poszczególnymi typami niepełnosprawności;

- historycznie przekazany stosunek do kwestii poszanowania człowieka, jego praw, indywidualności, wartości i niepowtarzalności;

- historycznie przekazany stosunek wobec uniwersalnych wartości oraz postaw pomocowo-empatycznych i humanistycznych adresowanych do ludzi i środowisk potrzebujących pomocy, a także indywidualno-społecznego wsparcia;

- przekazany, jako dominujący, nurt religijny.

2. Obszar uwarunkowań związanych z specyfiką rozwoju współczesnej cywilizacji:

- postęp naukowo-techniczny oraz jego wpływ na życie codzienne współczesnych ludzi;

- rozwój nowych technik komunikacyjnych, komunikacji masowej, mass mediów;

- zmiany w systemie wartości (dewaluacja wielu dotychczasowych wartości, nawet tych uniwersalnych);

- większa akceptacja dla postaw i zachowań, które dotychczas nie uzyskiwały akceptacji ogólnospołecznej i indywidualnej;

- anomia i alienacja ludzi oraz społeczeństw;

- rozwój dyscyplin naukowych mogących wywoływać wątpliwości natury etycznej, np. genetyka (maskująca eugenikę), nanotechnologia, biotechnologia, krionika i inne;

- odradzanie się koncepcji i działań eugenicznych w kontekście tzw. eugeniki pozytywnej oraz negatywnej;

- brak autorytetów moralnych stanowiących możliwe źródło naśladowania sposobu myślenia i postępowania;

- dewaluacja autorytetu Kościoła i roli religii w życiu ludzi;

- cyborgizacja i algorytmizacja (schematyzacja) życia ludzkiego (tzn. sposobów działania oraz myślenia - powierzchowne, płytkie, nie refleksyjne);

- tendencja kultu ciała, zdrowia, wysokiej sprawności (w tym wysokiej sprawności intelektualnej) - co ma istotne znaczenie dla problematyki niepełnosprawności w korelacie jej podmiotu;

- zauważalna dewaluacja jakości kształcenia (w tym kształcenia na poziomie wyższym), jego społecznego statusu i kulturowo wyznaczonej misji; 
- coraz częściej obecna w zachowaniu współczesnych ludzi tendencja nacelowana na preferencję interesu własnego nad dobrem, potrzebami i oczekiwaniami innego człowieka;

- wpływ korporacji i korporacyjnego myślenia (zdeterminowanego interesami określonych grup decydentów) na życie współczesnych społeczeństw, na kreowanie polityki ogólnoświatowej oraz działań realizowanych przez rządy poszczególnych państw w różnych, istotnych dziedzinach życia ludzkiego (opieka medyczna, edukacja, pomoc i wsparcie społeczne, aktywność w czasie wolnym).

3. Obszar uwarunkowań związanych ze specyfiką aktualnych społeczno-politycznych działań na rzecz osób niepełnosprawnych:

- sposób, jakość oraz efektywność dostosowania działań i zachowań ludzi angażujących się w pomoc udzielaną osobom niepełnosprawnym do specyfiki współczesnej rzeczywistości;

- nacelowanie na kwestie autonomii, podmiotowości, integracji, inkluzji, normalizacji, autorewalidacji, które bez właściwego ugruntowania treściowego i interpretacyjnego oraz przy ich bezpośrednim i nieodpowiedzialnym przełożeniu na działania wobec niepełnosprawnych i ich środowisk mogą okazać się przeciwstawne postulowanej w nich istocie, co może oznaczać działanie przeciwko problematyce niepełnosprawności;

- potrzeba uwzględnienia interdyscyplinarności i trans-dyscyplinarności w aktualnych działaniach realizowanych wobec osób z niepełnosprawnością;

- niedostateczne kryteria selekcji osób pełnosprawnych do realizacji pomocy osobom niepełnosprawnym (szczególnie chodzi o wymóg posiadania predyspozycji wewnętrznych i powołania do pracy z osobami niepełnosprawnymi oraz na ich rzecz);

- niewystarczająca koordynacja i spójność działań instytucji oraz organizacji działających na rzecz osób z niepełnosprawnością, skutkująca między innymi powielaniem, a nawet pozorowaniem realizowanych działań;

- możliwości finansowe państwa, stopa życiowa oraz jakość życia społeczeństwa;

- traktowanie niepełnosprawności w niektórych środowiskach i przy dużym bezrobociu jako sposobu na zabezpieczenie finansowego minimum egzystencji;

- niewystarczające rozwiązania prawno-legislacyjne (luki prawne, zawiłość obecnych przepisów) adresowane do środowiska niepeł- 
nosprawnych oraz instytucji, organizacji i konkretnych osób działających lub chcących działać na ich rzecz.

4. Obszar uwarunkowań związanych z osobą niepełnosprawną:

- akceptacja stanu własnej niepełnosprawności oraz wynikających z niej konsekwencji;

- cechy osobowe (w tym charakterologiczne): samoocena, autonomia, decyzyjność, zdeterminowanie na realizację założonych celów życiowych, stabilność działaniowa i emocjonalna;

- ukierunkowanie na autorehabilitację (autorewalidację) oraz działania na rzecz własnej sprawności;

- posiadany poziom wykształcenia oraz uzyskana specjalizacja zawodowa;

- miejsce zamieszkania, status społeczno-kulturowy (w tym status społeczno-kulturowy i ekonomiczny rodziny - a w tym tzw. rodziny pierwotnej - pochodzenia);

- sytuacja rodzinna własna oraz wychowanie w rodzinie w rodzinie pochodzenia.

5. Obszar uwarunkowań związanych z osobami pełnosprawnymi:

- deklarowana werbalnie a faktycznie prezentowana działaniowo-behawioralnie postawa wobec osób niepełnosprawnych oraz ich indywidualnych i społecznych możliwości;

- uwarunkowana czynnikami wewnętrznymi chęć działania na rzecz niepełnosprawnych i okazywania prawdziwej, rzeczywistej oraz nieargumentowanej względami wyłącznie ekonomicznymi pomocy;

- cechy osobowe: empatia, życzliwość, umiejętność zrozumienia problemów i sytuacji życiowej innego człowieka;

- cechy działaniowe - behawioralne: umiejętności organizacyjne, korzystania $z$ istniejących rozwiązań prawnych oraz możliwości finansowych dotyczących wspomagania niepełnosprawnych w różnych obszarach i sferach ich aktywności życiowej (w tym w sferze aktywności zawodowej);

- status, możliwości finansowe i decyzyjności realizowanej aktywności zawodowej.

\section{Podsumowanie}

Rozwój ludzkości, cywilizacji nie stoi w miejscu, charakteryzuje się bardziej lub mniej zauważalnymi tendencjami zmiany istniejących dokonań histo- 
ryczno-kulturowych, rozwiązań społeczno-politycznych, dominujących aktywności indywidualnych i zbiorowych, preferowanych wartości i norm etycznych, zarówno w życiu całych społeczności, jak i indywidualnych ludzi.

Stąd aktualna rzeczywistość stawia współczesnego człowieka przed wieloma poważnymi, zróżnicowanymi, nowymi wyzwaniami, nieznanymi w epokach przeszłych. To wyzwania zarówno o charakterze globalnym, ogólno-cywilizacyjnym, jak i o charakterze indywidualnym, tj. dotyczące subiektywnej percepcji obecnych osiągnięć nauki, techniki czy osiągnięć własnych w relacji do wymogów życia w społeczeństwie nowej wiedzy, nowych technologii i nowych wartości.

Nie budzi obecnie sprzeciwu stwierdzenie, że żyjemy w okresie transformacji naukowych, społecznych, aksjologicznych, ewolucyjnych, które wymagają od osoby ludzkiej odnalezienia się w otaczającym świecie i swojego w nim miejsca - takiego, by dawało maksymalnie możliwą autonomię, samorealizację oraz zadowolenie $z$ własnego istnienia. Zmiany cywilizacyjne dotyczą również osób niepełnosprawnych, które z uwagi na niepełnosprawność i jej specyfikę warunkowaną rodzajem konsekwencji doświadczanego stanu niepełnosprawności oraz jakością działań społecznych adresowanych do osób z niepełnosprawnością, a także wykazywaną aktywnością własną, muszą sprostać tym niemałym wymogom i odnaleźć nie tylko swoje miejsce w życiu. Również możliwych dróg i sposobów samorealizacji, między innymi w sferze aktywności społeczno-zawodowej, na zasadach maksymalnie możliwej konkurencyjności z osobami pełnosprawnymi.

Nie jest to zadanie łatwe, ale też nie jest to zadanie niemożliwe do wykonania. Uda się je zrealizować przy odpowiednio zorganizowanej, ukierunkowanej na niezbędną pomoc, specjalistyczne wsparcie (rehabilitacyjne, edukacyjne, społeczne, środowiskowe, prawne), aktywizacji posiadanych zasobów, a także przy ukształtowaniu indywidualnych mechanizmów samodzielnego radzenia sobie w różnych sytuacjach i z różnymi problemami. Jedynie skonsolidowane działanie specjalistów pracujących ze środowiskiem osób z niepełnosprawnością, samych osób niepełnosprawnych i ich rodzin może, i powinno, przyczynić się do zmiany sytuacji osobistej oraz społeczno-zawodowej tych osób w dobie coraz wyższych wymogów stawianych współczesnym ludziom w odniesieniu do niezbędnej wiedzy, kompetencji i konkurencyjności w różnych obszarach ich aktywności egzystencjalnej. 


\section{6 | Marzenna Zaorska}

\section{Bibliografia}

Raport o osobach niepetnosprawnych w Polsce. Kobiety dla Polski. Polska dla kobiet, Biuro Prasowe Kongresu Kobiet, Warszawa 2011.

Wojewódzki program wyrównywania szans i przeciwdziałania wykluczeniu społecznemu oraz pomocy $w$ realizacji zadań na rzecz zatrudniania osób niepełnosprawnych na lata 2012-2015. Monitoring działań w 2013 roku w obszarze: bezrobotne osoby niepetnosprawne, Wojewódzki Urząd Pracy, Olsztyn 2013. 